\title{
Effects of Cyphomandra betacea Seedlings Intercropping with Hyperaccumulators on Soil Enzyme Activity under Cadmium Stress
}

\author{
Shuling Zheng ${ }^{1, a}$, Jin Wang ${ }^{2, b}$ and Lijin Lin ${ }^{2, c *}$ \\ ${ }^{1}$ College of Horticulture, Sichuan Agricultural University, Chengdu, Sichuan, China \\ ${ }^{2}$ Institute of Pomology and Olericulture, Sichuan Agricultural University, Chengdu, Sichuan, China \\ a630668750@qq.com, b251040278@qq.com, cllj800924@qq.com
}

${ }^{*}$ Corresponding author. Shuling Zheng and Jin Wang contributed equally to this work.

\begin{abstract}
Keywords: Intercropping; Cyphomandra betacea Seedlings; Soil Enzyme Activity; Cadmium Abstract: The effects of Cyphomandra betacea seedlings intercropping with four hyperaccululator plant species (Bidens pilosa, Solanum photeinocarpum, Galinsoga parviflora, and Tagetes erecta) on soil enzyme activity under cadmium $(\mathrm{Cd})$ stress were studied by a pot experiment. The results showed that intercropping treatments could increase the soil sucrase and soil urease activities. The soil catalase and soil polyphenol oxidase activities showed different promote or inhibit effects on different hyperaccumulator plants by intercropping compared to monoculture. Only intercropping with $S$. photeinocarpum, all soil enzyme activity increased compared to $C$. betacea monoculture. Therefore, intercropping could improve the soil enzyme activity under $\mathrm{Cd}$ stress, and $C$. betacea intercropping with $S$. photeinocarpum was the best.
\end{abstract}

\section{Introduction}

Cadmium (Cd) is a heavy metal with the characteristics of constant accumulation, difficult to eliminate and highly toxic on plants [1]. Excessive amount of $\mathrm{Cd}$ inhibits the soil enzyme activity, so that soil enzyme activity can be used as an index to judge the degree of heavy metal pollution and crop damage [2-3]. Cyphomandra betacea is a perennial fruit tree, which has both edible and ornamental value [4], and it is also contaminated with cadmium [5]. Rational intercropping can change the effective state of heavy metals and affect the absorption by plants, and improve soil microbial diversity and soil enzyme activity [6-7]. The studies show that the heavy metal uptake in non-hyperaccumulator plants reduces and hyperaccumulator biomass and heavy metal absorption effect improves by intercropping [8-9]. Therefore, in this study, we used four Cd-hyperaccumulator plant species Bidens pilosa [10], Solanum photeinocarpum [11], Galinsoga parviflora [12], and Tagetes erecta [13] to intercrop with $C$. betacea seedlings under $\mathrm{Cd}$ stress to study the effects on soil enzyme activity.

\section{Materials and Methods}

Materials. In October 2013, the seeds of four hyperaccumulator plant species B. pilosa, $S$. photeinocarpum, G. parviflora, and T. erecta were collected from the farmland of the Ya'an campus farm of the Sichuan Agricultural University. In May 2014, the seeds were put in the climate chamber to germination and further cultivation. The seeds of $C$. betacea were harvested from 10-year-old fruit of the farmland of the Ya'an campus farm of the Sichuan Agricultural University November 2013. In April 2014, the seeds were put in the climate chamber to germination and further cultivation.

Experimental Design. In April 2014, the soil was air-dried and passed through a 6.72-mm sieve. $2.5 \mathrm{~kg}$ air-dried soil was weighed into each plastic pot $(21 \mathrm{~cm}$ high, $20 \mathrm{~cm}$ in diameter $)$, soaking uniformly by $10 \mathrm{mg} / \mathrm{kg} \mathrm{Cd}$ (in the form of $\mathrm{CdCl}_{2} \cdot 2.5 \mathrm{H}_{2} \mathrm{O}$ ) solution for 30 days. All pots were watered each day to keep the soil moisture about $80 \%$. In June 2016, three uniform-sized seedlings (the shoots were about $10 \mathrm{~cm}$, three true leaves expanded) of $C$. betacea were transplanted into pot for monoculture. One uniform-sized seedling (the shoots were about $3 \mathrm{~cm}$, two true leaves expanded) of each four hyperaccumulators and two $C$. betacea seedlings were transplanted into 
each pot for intercropping. The monoculture of $C$. betacea was planted three seedlings for one pot. For each treatment with six replicates and the pots placed completely random. The distance between pots was $15 \mathrm{~cm}$, and the pot position exchanged aperiodically to weaken the impact of the marginal effects. The soil moisture content was maintained at $80 \%$ of field capacity until the plants were harvested.

After 60 days, remove and blending $0-5 \mathrm{~cm}$ soil of every pot, encapsulated with plastic bags to be kept in laboratory at $4^{\circ} \mathrm{C}$ refrigerator. After soil through a $1 \mathrm{~mm}$ sieve, determined the soil enzyme activity [14]. Determination methods of soil catalase activity was potassium permanganate titration, soil urease activity was indigo blue colorimetry, soil sucrase activity was 3N-5-dinitrosalicylic acid colorimetry, and soil polyphenol oxidase activity was colorimetric method [15].

Statistical Analyses. Statistical analysis was carried out by using SPSS 20.0 statistical software. The data were analyzed by one-way ANOVA, with the least significant difference at the 5\% confidence level.

\section{Results and Discussion}

Soil Catalase Activity. Compared with the monoculture of C. betacea, intercropping with B. pilosa and $T$. erecta decreased the soil catalase activity under $\mathrm{Cd}$ stress, and intercropping with $S$. photeinocarpum and G. parviflora increased the soil catalase activity under Cd stress (Fig. 1). The soil catalase activity by intercropping with $B$. pilosa and T. erecta, decreased by $6.61 \%(p>0.05)$ and $0.88 \%(p>0.05)$, respectively compared to monoculture. Intercropping with $S$. photeinocarpum and G. parviflora increased by $8.81 \%(p>0.05), 9.69 \%(p>0.05)$, respectively compared to monoculture.

Soil Polyphenol Oxidase Acrivity. The soil polyphenol oxidase activity was ranked in the following order: intercropping with $T$. erecta $>$ intercropping with $S$. photeinocarpum > monoculture > intercropping with $G$. parviflora $>$ intercropping with $B$. pilosa (Fig. 2). According to the order, they were respectively $0.53(p<0.05), 1.46(p<0.05), 0.86(p>0.05)$ and $1.47(p<$ $0.05)$ times of monoculture.

Soil Sucrase Acrivity. Compared with the monoculture, except intercropping with G. parviflora, the soil sucrase activity increased significantly by intercropping under Cd stress (Fig. 3). The soil sucrase activity by intercropping with $G$. parviflora decreased by $9.67 \%(p>0.05)$ compared to monoculture, intercropping with B. pilosa, S. photeinocarpum and T. erecta increased by $254.79 \%$, $147.01 \%$, and $34.18 \%$ respectively compared to monoculture.

Soil Urease Acrivity. Intercropping with four hyperaccumulators increased the soil urease activity compared to monoculture under Cd stress (Fig. 4). The soil urease activity was ranked as: intercropping with $S$. photeinocarpum > intercropping with $B$. pilosa $>$ intercropping with $T$. erecta $>$ intercropping with $G$. parviflora $>$ monoculture. According to the order, they were respectively $1.43(p<0.05), 1.88(p<0.05), 1.07(p>0.05)$ and $1.40(p<0.05)$ times of monoculture.

\section{Conclusions}

Under Cd stress, intercropping treatments could increase the soil sucrase and soil urease activities. The soil catalase and soil polyphenol oxidase activities showed different promote or inhibit effects on different hyperaccumulator plants by intercropping compared to monoculture. Only intercropping with $S$. photeinocarpum, all soil enzyme activity increased compared to $C$. betacea monoculture. Therefore, intercropping could improve the soil enzyme activity under Cd stress, and $C$. betacea intercropping with $S$. photeinocarpum was the best.

\section{Acknowledgements}

This work was financially supported by the Application Infrastructure Project of Science and Technology Department of Sichuan Province (2016JY0258). 


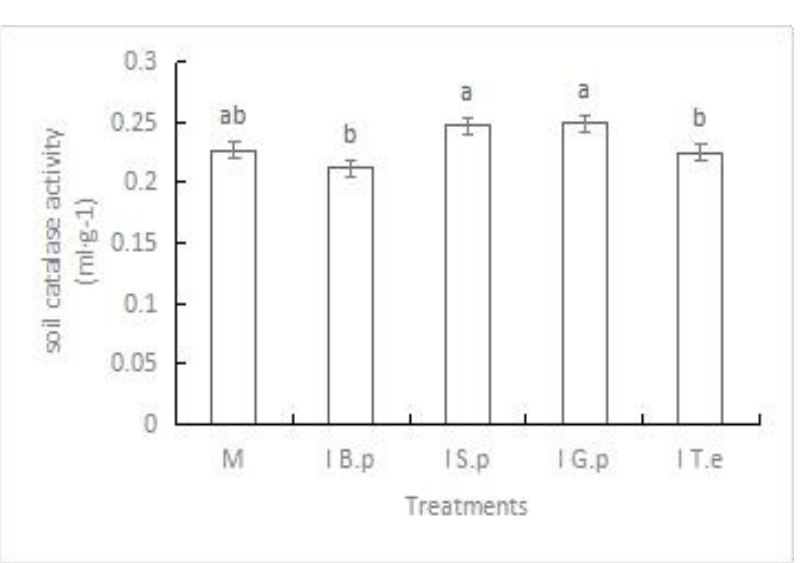

Fig. 1 Soil catalase activity. Different lowercase letters indicate significant differences based on one-way analysis of variance in SPSS 13.0 followed by the least significant difference test $(p<0.05) . \quad \mathrm{M}=$ monoculture, $\mathrm{I}$ B.p $=$ intercropping with $B$. pilosa, I S.p = intercropping with Solanum photeinocarpum, I G.p = intercropping with Galinsoga parviflora, I T.e = intercropping with $T$. erecta .

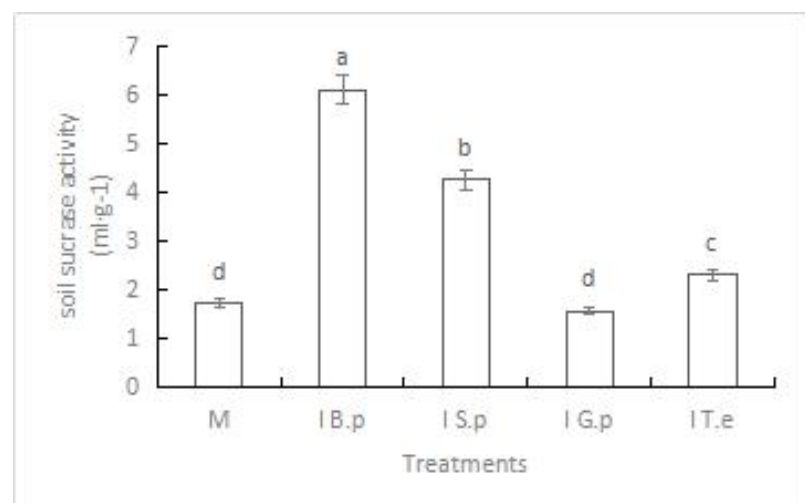

Fig. 3 Soil sucrase activity. Different lowercase letters indicate significant differences based on one-way analysis of variance in SPSS 13.0 followed by the least significant difference test $(p<0.05) . \quad \mathrm{M}=$ monoculture, $\mathrm{I}$ B. $\mathrm{p}=$ intercropping with B. pilosa, I S.p = intercropping with Solanum photeinocarpum, I G.p = intercropping with Galinsoga parviflora, I T.e = intercropping with $T$. erecta .

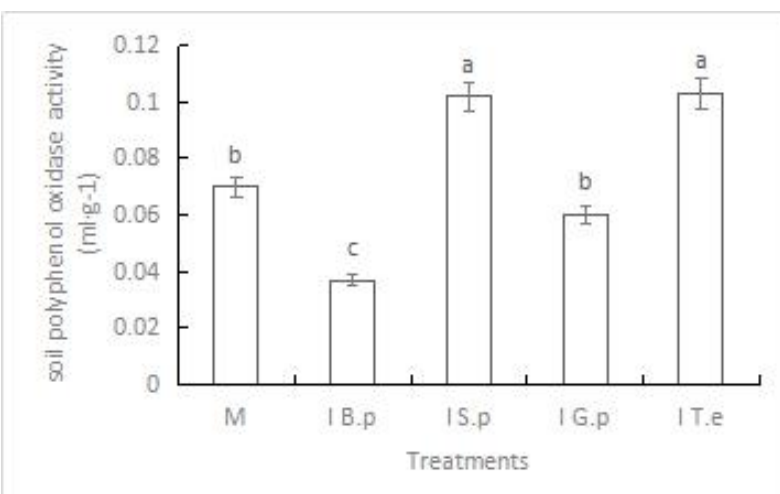

Fig. 2 Soil polyphenol oxidase activity. Different lowercase letters indicate significant differences based on one-way analysis of variance in SPSS 13.0 followed by the least significant difference test $(p<$ 0.05). $\mathrm{M}=$ monoculture, I B.p = intercropping with B. pilosa, I S.p = intercropping with Solanum photeinocarpum, I G.p = intercropping with Galinsoga parviflora, I T.e = intercropping with $T$. erecta.

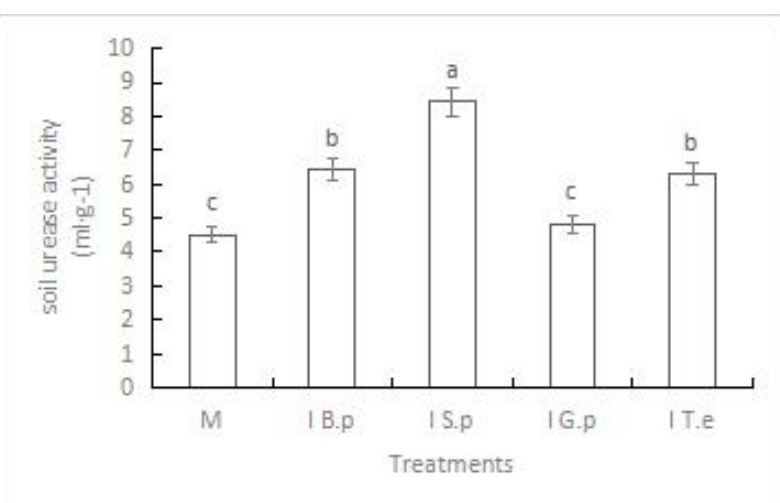

Fig. 4 Soil urease activity. Different lowercase letters indicate significant differences based on one-way analysis of variance in SPSS 13.0 followed by the least significant difference test $(p<0.05) . \quad \mathrm{M}=$ monoculture, $\mathrm{I}$ B. $\mathrm{p}=$ intercropping with $B$. pilosa, I S.p = intercropping with Solanum photeinocarpum, I G.p = intercropping with Galinsoga parviflora, I T.e = intercropping with $T$. erecta .

\section{References}

[1] M.A. Farooq, S. Ali, A. Hameed, S.A. Bharwana, M. Rizwan, W. Ishaque, M. Farid, K. Mahmood and Z. Iqbal: South African Journal of Botany Vol. 104 (2016), p. 61.

[2] L.P. Qiu and X.C. Zhang: Journal of Agro-Environment Science Vol. 25 (2006), p. 30.

[3] Q.F. Meng, J.S. Yang, R.J. Yao, S.P. Yu, C.Y. Zhang and R.L. Ji: Journal of Ecology and Environmental Sciences Vol. 21 (2012), p. 545. 
[4] J. He, L.J. Lin, J. Shi, Y.M. Tan, Q.Q. Ma, C.Y. Liu, J. Wen, J.J. Huang, C.C. Zhong and M.A. Liao: Journal of Soil Science Vol. 5 (2016), p. 1259.

[5] J.M. Tang, A.J. Yao and Y.H. Liang: Journal of Subtropical Resources and Environment Vol. 7 (2012), p. 27.

[6] Q. Chai, P. Huang and G.B. Huang: Journal of Acta Prataculturae Sinica Vol. 5 (2005), p. 105.

[7] N.Y. Li, Z.A. Li, Y.Z. Ding, B. Zou and P. Zhuang: Journal of Applied Ecology Vol. 19 (2008), p. 1369.

[8] S.N. Whiting, J.R. Leake, S.P. McGrath and A.J. Baker: Environmental Science and Technology Vol. 35 (2001), p. 3237.

[9] C.A. Jiang, Q.T. Wu, S.H. Wu and X.X. Long: Journal of China Environmental Science Vol. 9 (2009), p. 985.

[10] S.H. Wei, C.J. Yang and Q.X. Zhou: Journal of Environmental Science Vol. 29 (2008), p. 2912.

[11] X.F. Zhang, H.P. Xia, Z.A. Li, P. Zhuang and B. Gao: Journal of Hazardous Materials Vol. 189 (2011), p. 414.

[12] L.J. Lin, Q. Jin, Y.J. Liu, B. Ning, M.A. Liao and L. Luo: Environmental Toxicology and Chemistry Vol. 33 (2014), p. 2422.

[13] Z.G. Tian and F. Wang: Journal of Acta Botanica Boreali-Occidentalia Sinica Vol. 33 (2013), p. 2057.

[14] L.K. Zhou: Soil Enzymology (Science Press, Beijing 1987).

[15] S.Y. Guan: Soil Enzymes and Their Research Methods (Agricultural Press, Beijing 1986). 